\title{
29
}

\section{SOCIAL MEDIA RECRUITMENT OF AMERICANS}

\section{A case study from the Islamic State}

\author{
Alexander Meleagrou-Hitchens and Seamus Hughes
}

A new term has entered the counterterrorism lexicon in the past decade: the "virtual plotter."' This phrase, and variations of it, describe members of jihadi terrorist groups, mainly affiliated with the Islamic State, who use social media and applications with encryption technologies to reach out to and correspond with radicalized Westerners. In some cases, its members plot and direct attacks, helping to hone and focus the often-undisciplined zeal of potential lone actor terrorists to ensure that their eventual actions achieve either the maximum propaganda value or casualty impact. ${ }^{2}$

More frequently, however, these virtual plotters have acted in a more auxiliary capacity, plugging their Western contacts into wider extremist milieus (both online and offline) and encouraging radical beliefs while offering suggestions and options for mobilization. Indeed, because of the variety of roles they play, the authors have chosen to refer to these individuals as "virtual entrepreneurs," thus allowing for a broader encapsulation of the different categories of their involvement.

This chapter examines the impact of Islamic State ${ }^{3}$ virtual entrepreneurs in the United States. ${ }^{4}$ To present a broader and more accurate picture of how virtual entrepreneurs operate, the authors have categorized exchanges between U.S.-based Islamic State sympathizers and virtual entrepreneurs as either "direct plotting" or "encouragement and facilitation." " Out of a total of 38 Islamic State-inspired domestic plots and attacks in the United States between the period of March 1, 2014, and March 1, 2020, at least eight (21\%) involved some form of digital communication with Islamic State virtual entrepreneurs. ${ }^{6}$ In addition, virtual entrepreneurs have also been involved in at least six other terrorism-related cases, including assisting with logistics related to traveling to join the Islamic State. ${ }^{7}$ This brings the total number of U.S. terrorism cases linked to Islamic State virtual entrepreneurs to 14, involving 19 U.S.-based individuals, as of March 1, 2020.

\section{Background on virtual entrepreneurs}

The Islamic State's online contact with radicalized Westerners has given the group wider scope to claim ownership of attacks that in some cases it had little to do with in reality. This has inflated the Islamic State's impact and reach, which is crucial to the group's propaganda success. The emergence of Islamic State virtual entrepreneurs represents a hybrid between what are commonly seen as the two previous manifestations of the jihadi terrorist threat to the West: networked and inspired lone attacker plots. The former relies on direct involvement by an organization in terms of training, direction, financing, and indoctrination. The 
lone actor and now hybrid categories rely more on the creation of loosely connected milieus, often online, and the wide availability of an accessible form of global jihadi propaganda.

Law enforcement has understandably struggled to categorize this new development. In 2016, the Federal Bureau of Investigation's (FBI) executive assistant director for the National Security Division offered some measure of clarity. He described the current threat picture as "a hybrid between directed and enabled ... individuals overseas using encrypted communications to elicit some type of assistance from somebody in the U.S." He also pointed out that these figures often do not specifically direct attacks but rather help in "getting somebody ready to go . . getting them motivated, showing them a menu of targets and then saying, "hey, you take care of it."

While the use of this tactic has increased as the Islamic State continues to exploit social media and online encryption technologies, the phenomenon of jihadi entrepreneurs making virtual connections with unaffiliated radicalized Westerners is certainly not new. As is often the case when discussing innovative jihadis, one need only look at the activities of the late Yemeni-American al-Qaida ideologue and recruiter Anwar al-Awlaqi, who, via e-mail, was in contact with a number of radicalized individuals in the West and who, in at least one case, helped plot a potential attack. ${ }^{9}$

Social media and encrypted messaging apps, along with an expansion of jihadi territories across the globe, are all factors that have nonetheless added a new dimension to such virtual communications.

\section{Social media outreach to Americans}

In the United States, the impact of virtual entrepreneurs has not been as deadly as in Europe, but this is not for lack of effort. The most sustained attempts to import this type of terrorism to the United States came from a group that was based in Islamic State-held Raqqa, Syria, which the FBI nicknamed "the Legion." Composed of around a dozen English-speaking and mainly Western Islamic State operatives, the Legion systematically reached out to individuals in the United States using a mixture of direct messaging on Twitter and encrypted messaging. ${ }^{10}$ The group presented such a threat that three of its membersJunaid Hussain, Reyaad Khan, and Raphael Hostey-were killed in targeted airstrikes between 2015 and $2016 .{ }^{11}$

Hussain, the most prominent Legion member, was a British foreign fighter and former hacker. ${ }^{12}$ In 2013, while on bail for hacking charges, Hussain traveled to Islamic State-controlled territory and assumed the kunya (alias) Abu Hussain al-Britani. ${ }^{13}$ Before his death in August 2015, Hussain had achieved celebrity status among the online English-speaking Islamic State community. ${ }^{14}$ Both he and fellow British national Khan were identified by then-British Prime Minister David Cameron as being "involved in actively recruiting [Islamic State] sympathizers and seeking to orchestrate specific and barbaric attacks against the West." ${ }^{15}$ The other known British member of the Legion, Hostey (also known as Abu Qaqa), had traveled to Syria in 2013 and was mainly engaged in recruiting foreign fighters and creating Englishlanguage propaganda. ${ }^{16}$

The following vignettes reveal how members of the Legion actively sought to direct or encourage attacks in the United States. In some cases, Legion members were involved in direct plotting, instructing U.S. residents to commit attacks on behalf of the Islamic State, providing knowledge and guidance throughout the various elements of the plot. In others, Legion members simply encouraged and facilitated supporters in the United States to commit attacks without providing specifics or detailed instructions.

\section{Direct plotting}

Among the clearest examples of a Legion virtual entrepreneur directly plotting an attack is the case of Ohio resident Munir Abdulkader, who pleaded guilty to a plan to attack U.S. government officers. ${ }^{17}$ His flirtation with the Islamic State began in July 2014 when he established Twitter accounts to voice support 
for the group. ${ }^{18}$ Once he plugged himself into the online Islamic State community, it was not long until he came across and reached out to Legion figure Junaid Hussain, who largely became his handler in the spring of $2015 .{ }^{19}$

Initially, Abdulkader wanted to travel to Syria, but "Hussain helped push him to a different course" and turned his focus to a domestic attack "when they decided it simply had gotten too dangerous to go to an airport," explained Assistant U.S. Attorney Timothy Mangan, who prosecuted the case. ${ }^{20}$

Over the course of their communications, Hussain developed a terrorist plot for Abdulkader to implement. ${ }^{21}$ More specifically, he instructed Abdulkader to kidnap a U.S. soldier and record his murder on camera, providing him the target's name and address. The pair also discussed the best weapon to use and the need to record the attack for later propaganda dissemination. ${ }^{22}$ Following this conversation, Hussain suggested that Abdulkader attack a police station in Cincinnati, Ohio. Abdulkader also drew encouragement from Hussain that helped increase his determination to carry out a violent act. ${ }^{23}$ Abdulkader was ultimately sentenced to 20 years in prison for the thwarted plot. ${ }^{24}$

A second example relating to direct plotting also involved virtual entrepreneur Hussain. One of his main interests was inciting and planning attacks against people and groups seen as maligning the Prophet Muhammad. In mid-May 2015, David Daoud Wright, Nicholas Alexander Rovinski, and Usaamah Abdullah Rahim were in the advanced stages of a plan to kill an organizer of the "[Prophet] Muhammad Art Exhibit and [Cartoon] Contest," an event in Garland, Texas. Rahim, the senior member of the group, liaised with Hussain about possible attacks. The target was decided upon as a result of these conversations, during which "Hussain directly communicated instructions to Rahim with regard to the murder of [the] Intended Victim," which Rahim subsequently passed on to his accomplice, Wright. ${ }^{25}$

Due to the contact between Rahim and Hussain and subsequent activities by the plotters-including Rahim's purchase of combat knives at Hussain's recommendation "in case the 'feds' tried to arrest him" ${ }^{26}$ they soon became the subjects of law enforcement surveillance. On June 2, 2015, Rahim was approached by investigators while walking through a parking lot in Roslindale, Massachusetts, and he was shot dead after attempting to attack them with a knife. Rovinski was sentenced to 15 years in prison, ${ }^{27}$ and Wright was sentenced to 30 years. ${ }^{28}$

Legion members Hussain and Khan began their attempts to direct plots in the United States as early as 2014, when they used social media to solicit Minnesota resident Abdul Raheem Ali-Skelton to carry out an attack. ${ }^{29}$ During the previous months, Ali-Skelton had interacted and debated with Islamic State members on social media and was soon referred to the two Legion members. Ali-Skelton refused their request, however, but was later arrested and convicted for lying about his contact with the Legion. ${ }^{30}$

\section{Encouragement and facilitation}

While virtual entrepreneurs gain the most attention for their roles as direct plotters, much of their work has involved encouraging their contacts to take on more extreme positions or facilitating connections to real-world foreign fighter networks.

"Very soon carrying out 1st operation of Islamic State in North America," a user called "TheMujahid" texted to his online contact. The response was quick: "Can u make a video first?" Authorities determined that "TheMujahid" was North Carolina native Justin Sullivan, and his Islamic State contact was Legion member Hussain, who was writing under one of his several online monikers. ${ }^{31}$

According to documents from his case, messages found on Sullivan's cell phone showed that he "conspired and agreed with Hussain to commit such attacks on behalf of, and in support of, [the Islamic State] and in an effort to change United States policies against [the Islamic State] by avenging U.S.-coalition airstrikes against [Islamic State] fighters." ${ }^{32}$ Sullivan had converted to Islam in September 2014 and soon began reading Islamic State propaganda. In December 2014, he used his father's gun to murder his elderly neighbor, although the motive has never been fully established. ${ }^{33}$ 
By mid-2015, Sullivan had planned to buy an assault rifle at a local gun show and expressed a desire to kill up to 1,000 people. ${ }^{34}$ Perturbed by his son's behavior, which included destroying Buddha statues and other non-Islamic religious items, Sullivan's father called 911 and informed authorities of his suspicion that his son was becoming an Islamic State supporter. ${ }^{35}$

After subsequently entering into conversations with an FBI undercover agent in which he discussed his intentions to carry out an attack, he was arrested in June 2015 and pleaded guilty to providing material support to terrorism. Sullivan's case is indicative of the wider impact of virtual entrepreneurs in the United States beyond direct attack planning. ${ }^{36}$ Sullivan was not only provided with the encouragement, reassurance, and camaraderie he needed, but he also received specific advice on how to ensure his attack could provide the most benefit to the Islamic State.

Another U.S. case that sheds further light on the multifaceted role of virtual entrepreneurs is that of Jalil ibn Ameer Aziz of Pennsylvania. Prior to his arrest in December 2015 on charges of conspiracy to provide material support to the Islamic State, Aziz was heavily involved in online extremist networks, creating at least 57 pro-Islamic State Twitter accounts. ${ }^{37}$ When authorities searched his house, they discovered a tactical-style backpack with M4-style high-capacity magazines and a knife. ${ }^{38}$

Aziz helped connect aspiring American Islamic State foreign fighters with Legion members Hussain and Khan. According to court filings, Hussain provided Aziz with a Turkish telephone number, directing him to share it with a potential recruit so that he could communicate with them using encrypted messaging applications. Hussain also suggested to Aziz that if there were any problems, the recruit should contact another member of the Legion, Hostey, via a Twitter profile he provided. ${ }^{39}$

Legion member Hostey also communicated with at least two other Islamic State supporters. One of them, Avin Brown, was the first American to be arrested for trying to travel to join the Islamic State. ${ }^{40}$ Brown was friendly online with Hostey and helped connect him with another American Islamic State recruit, Mohammed Khan, from Chicago. ${ }^{41}$

Beginning in 2014, Khan initiated contact with Islamic State members overseas to seek guidance on traveling to Syria to join the group. ${ }^{42}$ In September 2014, Khan bought three airplane tickets from Chicago to Istanbul for himself and two siblings, but all three were arrested at O'Hare International Airport before boarding the flight. ${ }^{43}$ According to court documents, Hostey gave Khan information regarding routes to Syria, methods to avoid law enforcement suspicion, and the contact information of an individual in Istanbul who could take him into Islamic State-held territory in Syria. ${ }^{44}$

Between late 2015 and mid-2016, another domestic Islamist terrorist, Mohamed Bailor Jalloh, had been in communication with Islamic State virtual entrepreneur Abu Sa'ad al-Sudani. ${ }^{45}$ While not a member of the Legion, the Department of Defense identified al-Sudani as a "member, recruiter and external planner." ${ }^{46}$ Jalloh had traveled to Nigeria, via his native country of Sierra Leone, in June 2015, and he met an unnamed Islamic State facilitator with the intent of receiving assistance to join the group in Libya. He eventually decided against this and opted instead for a plan to attack the U.S. homeland. It was on his way back to the United States, while in Sierra Leone, that Jalloh first made online contact with al-Sudani. According to court documents, he was someone whom Jalloh "understood was an [Islamic State] figure engaged in plotting attacks in the United States." ${ }^{47}$

After his return to the United States, Jalloh communicated regularly with al-Sudani during the first half of 2016. On two separate occasions, al-Sudani arranged for a total of $\$ 700$ to be sent to him via a family member of Jalloh's in Sierra Leone, who gave the funds to a contact of al-Sudani's in the country. By March 2016, court records show that al-Sudani "was actively plotting an attack in the United States." As part of these efforts, he had put Jalloh in touch with another U.S.-based contact of his in the hope that they would plan an attack together. ${ }^{48}$

Unbeknownst to al-Sudani, his contact was an FBI informant. Jalloh first met the informant in April 2016 in Virginia and began discussing with him various options for an attack in the name of the Islamic State. During the meeting, Jalloh claimed that he was constantly thinking about conducting an attack, and when 
asked to elaborate, he said, "Nidal Hassan type of things. That's the kind of stuff I started thinking." ${ }^{49}$ As a result of the investigation, Jalloh was arrested in July 2016 after attempting to buy a weapon in North Carolina that he intended to use for an attack. He was later sentenced to 11 years in prison for conspiracy to provide material support to the Islamic State. ${ }^{50}$

Another example of virtual entrepreneur al-Sudani's involvement in encouragement and facilitation is the case of Aaron Daniels. Daniels, a 20-year-old resident of Ohio, was arrested in November 2016 for attempting to provide material support to the Islamic State. ${ }^{51}$ Federal agents apprehended Daniels as he left his hometown of Columbus. He intended to fly to Trinidad and Tobago to confuse authorities before attempting to continue onwards to join Islamic State affiliates in Libya or Syria. ${ }^{52}$ In addition to the attempted travel overseas, Daniels also sent \$250 via Western Union to an intermediary for al-Sudani in January $2016 .^{53}$

According to the criminal complaint, Daniels had been in contact with al-Sudani via social media before eventually sending him money and purchasing a plane ticket. ${ }^{54}$ In June 2016, Daniels told an undercover FBI agent that while he initially intended to join the jihad in Syria, "brother Abu Isa told me it was closed at that time . . . and suggested that I go to Libya." ${ }^{55}$ Later, Daniels clarified that he was in fact referring to al-Sudani. ${ }^{56}$ In a similar fashion to his other contacts with American would-be jihadis, al-Sudani provided advice and guidance about traveling overseas to join the Islamic State (for a fee) and additionally directed the recipient of his advice toward non-Syria battlefields. ${ }^{57}$

Al-Sudani was also involved in encouraging New York-based Islamic State supporter Emanuel Lutchman to plan an attack in the city. They began communicating online in December 2015 after Lutchman found al-Sudani's contact in an Islamic State-produced online document. ${ }^{58}$ During these discussions, Lutchman expressed his desire to travel to Libya to join the Islamic State, but he was told by al-Sudani that he first had to prove himself to the group by executing an attack in the United States.

Al-Sudani also pointed out that due to his location "behind enemy lines," Lutchman's real utility was as a domestic terrorist. ${ }^{59}$ He told Lutchman to plan an attack for New Year's Eve 2015, when he would have easy access to large crowds. He also offered Lutchman various pieces of advice both to ensure that the operation was as effective as possible and to avoid capture beforehand. Once the operation was complete, al-Sudani promised Lutchman he would vouch for him to the Islamic State after he arrived in Libya.

By late December, Lutchman-while maintaining regular contact with al-Sudani, who continued to offer advice and moral support - had begun plotting an attack with three accomplices. He was unaware, however, that all of these individuals were working for the FBI. On December 28, Lutchman identified a restaurant in Rochester, New York, as a target and began planning an attack that entailed taking hostages and executing them with a machete. ${ }^{60}$ Two days later, he recorded the video al-Sudani had requested of him. Holding his index finger aloft, he pledged allegiance to the Islamic State and announced that "the blood that you spill of the Muslim overseas, we gonna spill the blood of the kuffar [unbelievers]." ${ }^{61} \mathrm{He}$ was arrested immediately afterward, and in August 2016, Lutchman pleaded guilty to conspiracy to provide material support to the Islamic State and was sentenced to 20 years in prison. ${ }^{62}$ Al-Sudani died in a U.S. airstrike in Syria in April 2016. ${ }^{63}$

While Hussain provided instructions in a separate plot to attack the organizer of the Muhammad Art Exhibit and Contest, he was also, at the very least, on the periphery of a major conspiracy to attack the event itself. On May 3, 2015, Elton Simpson and his accomplice Nadir Soofi traveled to Garland, Texas, as part of a plot to use assault rifles to kill attendees. In the months preceding the attack, which ended in the deaths of both men before they could enter the venue, Simpson had been in direct contact with at least two virtual entrepreneurs using Twitter direct messages and SureSpot. ${ }^{64}$

Shortly before Simpson attempted the attack, he logged on to Twitter and urged users to follow@_ AbuHu55ain, one of the accounts operated by Legion member Hussain. ${ }^{65}$ In addition, an hour before the attack, Hussain himself tweeted a number of messages suggesting he was aware of the impending shooting, including: "The knives have been sharpened, soon we will come to your streets with death 
and slaughter!" 66 Two days later, the Islamic State released a statement taking credit for the attack in what amounted to its first of several claims of operations in the United States. ${ }^{67}$

While the clues certainly exist, there is no clear evidence that Hussain had a direct hand in plotting the attack in Garland, although there is no doubt he encouraged Simpson's extremism by offering moral support and helping validate his beliefs. While discussing Hussain's role in the Abdulkader case, however, Assistant U.S. Attorney Timothy Mangan told the judge that Hussain had boasted to Abdulkader about his involvement in directing the Garland attacks, telling him "there's more to come." ${ }^{8}$ Furthermore, in December 2015, FBI Director James Comey claimed that on the day of the attack, one of the gunmen and "an overseas terrorist" exchanged 109 encrypted messages. The overseas terrorist was reportedly thought to be Hussain. The details of these encrypted exchanges remain unknown, with the FBI unable to access them. ${ }^{69}$

Hussain was not the only virtual entrepreneur with whom Simpson had contact. Several years prior, Simpson attempted to join al-Shabaab in Somalia. ${ }^{70}$ Simpson's interest in this broader movement led him to Mohamed Abdullahi Hassan (a.k.a. "Mujahid Miski”), a Somali-American from Minnesota who joined alShabaab in 2009. ${ }^{71}$ Via direct messages on Twitter, Hassan and Simpson communicated about the Garland plot, with Hassan eventually re-tweeting a message from Simpson concerning the cartoon contest with a statement: "The brothers from the Charlie Hebdo attack did their part. It's time for brothers in the \#US to do their part." 72 This was a reference to the January 2015 al-Qaida-linked killings at the offices of French satirical magazine Charlie Hebdo, known for its frequent depictions of the Prophet Muhammad.

The virtual entrepreneurs of the Islamic State appear to be issuing similar sets of instructions to their American contacts, almost as if they are working from a common script. While it is unclear if Islamic State virtual entrepreneurs are sharing information and tradecraft among themselves, this certainly would appear to be the case.

Beyond their various degrees of direct contact with a myriad of radicalized Americans, the impact of virtual entrepreneurs, while significant, is difficult to measure. Their activities and the public profiles they cultivated have nonetheless made them beacons of inspiration for their fellow Western jihadis, many of whom have no doubt been motivated after witnessing their achievements.

\section{Implications of evolving social media and encryption technologies}

Social media, coupled with the ever-increasing availability of applications that offer encrypted messaging, has given virtual entrepreneurs the ability to both bypass Western counterterrorism measures and build close, trusted online relationships with recruits. Although jihadi propaganda has been easily accessible through various online platforms over the last decade, the advent of these social media applications has given would-be recruits access to real-time support and a stronger sense of belonging to the wider jihadi movement. This online support sustains and encourages a recruit's continued participation in the Islamic State.

In the past, American jihadis also sought religious justification and validation for their intended actions from recognized extremist leaders. Today, they can receive this from foreign fighters in Syria and Iraq. The deaths of figures like Hussain may help stem the number of homegrown attacks and plots, but the experience of the last six years points to an emerging online approach that is likely here to stay.

Along with helping to inspire radicalized Westerners, the work of Islamic State virtual entrepreneurs has given the group new ways to take ownership of attacks, ensuring that they continue to receive attention and media coverage. Crucially, virtual entrepreneurs require few resources and offer a favorable balance between cost and benefit. This is particularly pertinent, as the Islamic State lost ground in Iraq and Syria but retains its desire to remain relevant; by maintaining a significant online presence, its virtual entrepreneurs can give the group the capability to plot or encourage attacks on Western targets. ${ }^{73}$ 
It is, therefore, no surprise that this trend is on the rise. In Europe, the strengthening of security measures and increased military presence-after an initial period of lax oversight - has made it difficult for aspiring militants to travel and join the Islamic State as well as for the group to train and send operatives back to their home countries to conduct attacks. In the United States, it has never been easy to travel to Islamic State-controlled territory.

Three of the most influential members of the Legion-Hussain, Hostey, and Khan-were killed in 2015 and 2016, while Hassan was arrested in 2015 and al-Sudani was killed in 2016. Whether they can be replaced remains to be seen.

There are a number of factors that may influence this. The first is whether the Islamic State and other jihadi groups intent on striking the West are able to regain the territory needed to harbor individuals with the capability to inspire and plan attacks via the internet. While virtual entrepreneurs can technically be just as effective while operating outside of jihadi-held territory, it is more difficult. They may lose credibility in the eyes of Western jihadis gained by the likes of Hussain and Hassan who, due to their locations, were able to present themselves as legitimate members of terrorist organizations. This potential lack of safe havens would also likely make virtual entrepreneurs more vulnerable to interception by Western security services.

Second, much will depend on how both Western states and technology companies respond to this challenge. In August 2016, for example, Twitter announced that it had shut down 360,000 accounts for "promotion of terrorism." ${ }^{74}$ Nevertheless, it remains unclear how other companies that offer messenger apps with encryption services plan to respond. While Telegram announced in 2015 that it had shut down 78 Islamic State-related unencrypted channels, it also clarified that it had not interfered with any private, encrypted chats. ${ }^{75}$ Other encrypted messaging services echo this view.

In the traditional policy realm, Western states continue to struggle in their efforts to develop effective and coherent policies on combating terrorist use of the internet. In Europe, Europol has set up the Internet Referral Unit. According to Europol Deputy Director Wil van Gemert, it "detects terrorist and violent extremist online content, flags and refers such content to internet providers, and asks for its removal." ${ }^{, 76}$ It is not clear, however, if the Internet Referral Unit has begun to look into encrypted messaging applications.

In the United States, policy is still taking shape. Under the Barack Obama administration, government officials repeatedly met with senior technology company executives and through an initiative known as the Madison Valleywood Project urged them to police their platforms further and more aggressively enforce their terms of service. ${ }^{77}$ Overall, tensions are increasing between governments and companies that offer encrypted messaging platforms, with elected officials from both parties suggesting changes to Section 230 of the Communications Decency Act, which protects technology companies from being legally liable for the content on their platforms. ${ }^{78}$

The challenge of virtual entrepreneurs is intrinsically and inescapably entangled within the wider and overlapping issues of online privacy, countering violent extremism policies, and the ongoing tug of war between civil liberties and security. The future direction and shape of this debate, and the positions of tech companies and governments on censorship and monitoring of the internet, will ultimately decide how this new threat evolves.

As the response to this challenge develops, it is unlikely the world has seen the end of virtual entrepreneurs with the deaths of Legion members and others associated with them. Their recent successes could ensure that they will be central to jihadi groups' current and future efforts to strike the West while continuing to pose a complex challenge to counterterrorism authorities.

\section{Notes}

1 Rukmini Callimachi, "Not 'Lone Wolves' After All: How ISIS Guides World's Terror Plots From Afar,” New York Times, February 4, 2017, www.nytimes.com/2017/02/04/world/asia/isis-messaging-app-terror-plot.html; 


\section{Meleagrou-Hitchens and Hughes}

Daveed Gartenstein-Ross and Madeleine Blackman, "ISIL's Virtual Planners: A Critical Terrorist Innovation," War on the Rocks, January 4, 2017, https://warontherocks.com/2017/01/isils-virtual-planners-a-critical-terroristinnovation/; Bridget Moreng, "ISIS'Virtual Puppeteers," Foreign Affairs, September 21, 2016, www.foreignaffairs. com/articles/2016-09-21/isis-virtual-puppeteers.

2 The plots are often referred to as "Islamic State-enabled." While this typology is useful, it is also problematic, as it may suggest that the plots are planned by Islamic State leadership. It remains unclear if Islamic State virtual entrepreneurs are taking direction from senior Islamic State figures or acting independently.

3 While other jihadi groups, such as al-Qaida, have also made use of such platforms, the Islamic State is widely recognized as pioneering, or at least perfecting, the use of the internet to reach out to sympathizers around the world.

4 It is based on a review of court filings and interviews with law enforcement officials, reporters, and attorneys connected to these cases.

5 While such an approach is useful and necessary to better understand the threat, the levels of involvement of virtual entrepreneurs remain fluid and defy precise categorization.

6 The eight separate plots involved 13 individuals in total. They are Fareed Mumuni and Munther Omar Saleh (2015), David Daoud Wright and Nicholas Rovinski (2015), Munir Abdulkader (2015), Justin Nojan Sullivan (2015), Jalil Ibn Ameer Aziz (2015), Emanuel Lutchman (2015), Abdul Malik Abdul Kareem (2015), and Mohamed Bailor Jalloh (2016). The dates provided here reflect when the defendants were charged, as opposed to when the offense was carried out or contact was made with the virtual entrepreneur. Three individuals were killed either conducting their operation or during attempts to arrest them. Garland attackers Nadir Soofi and Elton Simpson were killed while conducting their operation. Usaamah Abdullah Rahim was killed when officers tried to arrest him. Soofi and Simpson committed the attack with assistance from Abdul Malik Abdul Kareem.

7 They are Avin Brown (2014), Mohammed Hamzah Khan (2014), Nader Elhuzayel (2015), Ardit Ferizi (2015), Aaron T. Daniels (2016), and Abdul Raheem Habil Ali-Skelton (2016).

8 Michael B. Steinbach, How Technology Has Transformed the Terrorist Threat Fifteen Years After 9/11 (Washington, DC: The Washington Institute, 2016).

9 This was the case of British Airways employee Rajib Karim. For more, see Alexander Meleagrou-Hitchens, As American as Apple Pie: How Anwar al-Awlaki Became the Face of Western Jihad (London: International Centre for the Study of Radicalisation and Political Violence, 2011); Scott Shane, Objective Troy (New York: Tim Duggan Books, 2016).

10 The membership of the Legion has yet to be fully identified. At the very least, it publicly consisted of British citizens Junaid Hussain (also known as Abu Hussain al-Britani) and his wife, Sally Jones (also known as Umm Hussain al-Britani); Reyaad Khan (also known as Abu Dujana); Raphael Hostey (also known as Abu Qaqa); and Trinidadian citizen Shawn Parson (also known as Abu Khalid al-Amriki). Based on conversations with individuals familiar with the group, the authors also strongly suspect that another British national, Omar Hussain (also known as Abu Sa'eed al-Britani), is also a member. Abu Sa'ad al-Sudani was not a member of the Legion but had close coordination with the group. For example, in at least one instance, Omar Hussain edited the online postings of al-Sudani. For more, see Adam Goldman and Eric Schmitt, "One by One, ISIS Social Media Experts Are Killed as Result of F.B.I. Program,” New York Times, November 24, 2016, www.nytimes.com/2016/11/24/world/middleeast/isisrecruiters-social-media.html.

11 Chris Cole, "Truth and Consequences: One Year on What We Know (and What We Don't) About the Khan Killing," Drone Wars, August 18, 2016, https://dronewars.net/2016/08/18/truth-and-consequences-one-year-onwhat-we-know-and-what-we-dont-about-the-khan-killing/.

12 U.S.A. v. Justin Nojan Sullivan, Factual Basis (Western District of North Carolina, 2016), 4.

13 Ibid., 4-5.

14 Hussain is thought to have been killed in a British operation codenamed "Illuminative" involving a U.S. airstrike.

15 "Cardiff Jihadist Reyaad Khan, 21, Killed by RAF Drone," BBC, September 7, 2015, www.bbc.com/news/ uk-wales-41406470.

16 William Watkinson, “Baby-Faced Isis Recruiter From Manchester Killed in Syria, Say Reports,” International Business Times, May 2, 2016, www.ibtimes.co.uk/baby-faced-isis-recruiter-manchester-killed-syria-say-reports-1557850.

17 U.S.A. v. Munir Abdulkader, Information (Southern District of Ohio, 2016); U.S.A. v. Munir Abdulkader, Affidavit in Support of a Criminal Complaint (Southern District of Ohio, 2015), 3.

18 U.S.A. v. Munir Abdulkader, Plea Agreement (Southern District of Ohio, 2016), 8; U.S.A. v. Munir Abdulkader, Information, 2; U.S.A. v. Munir Abdulkader, Criminal Complaint, 1.

19 According to court documents, Abdulkader "was in electronic communication with at least one member of ISIL overseas named Junaid Hussain, and placed himself under the direction of ISIL and its overseas leadership." See U.S.A. v. Munir Abdulkader, Sentencing Memorandum (Southern District of Ohio, 2016), 3.

20 U.S.A. v. Munir Abdulkader, Sentencing Minutes (Southern District of Ohio, 2016), 55. 


\section{Social media recruitment of Americans}

21 U.S.A. v. Munir Abdulkader, Sentencing Memorandum, 10.

22 U.S.A. v. Munir Abdulkader, Sentencing Minutes, 68 and 78.

23 U.S.A. v. Munir Abdulkader, Sentencing Memorandum, 13.

24 Office of Public Affairs, "Ohio Man Sentenced to 20 Years in Prison for Plot to Attack U.S. Government Officers," U.S. Department of Justice, November 23, 2016, www.justice.gov/opa/pr/ohio-man-sentenced-20-yearsprison-plot-attack-us-government-officers.

25 U.S.A. v. David Daoud Wright, Second Superseding Indictment (District of Massachusetts, 2017), 5.

26 Ibid.

27 Alanna Durkin Richer, “Man Guilty in Terror Plot to Be Released from Prison,” Associated Press, August 13, 2020, https://abcnews.go.com/US/wireStory/man-guilty-terror-plot-released-prison-72350803.

28 Joe Dwinell, "Convicted ISIS Terrorist out to Kill Boys in Blue Being Resentenced," Boston Herald, September 28, 2020, www.bostonherald.com/2020/09/28/convicted-isis-terrorist-out-to-kill-boys-in-blue-being-resentenced/.

29 U.S.A. v. Abdul Raheem Ali-Skelton, Defendant's Position on Sentencing Factors (District of Minnesota, 2016).

30 Laura Yuen, "Minnesotan Gets 3 Years for Lying About Contact with ISIS," MPR News, January 10, 2017, www. mprnews.org/story/2017/01/10/minnesotan-sentenced-lying-contact-isis.

31 U.S.A. v. Justin Nojan Sullivan, Factual Basis, 2, 5, and 15.

32 Ibid., 21.

33 Ibid., 2.

34 U.S.A. v. Justin Nojan Sullivan, Criminal Complaint (Western District of North Carolina, 2016), 4.

35 Ibid.

36 Office of Public Affairs, "North Carolina Man Pleads Guilty to Attempting to Commit an Act of Terrorism Transcending National Boundaries," U.S. Department of Justice, November 29, 2016, www.justice.gov/opa/pr/ north-carolina-man-pleads-guilty-attempting-commit-act-terrorism-transcending-national.

37 U.S.A. v. Jalil Ibn Ameer Aziz, Criminal Complaint (Middle District of Pennsylvania, 2015), 13.

38 Ibid., 14.

39 U.S.A. v. Jalil Ibn Ameer Aziz, Government's Opposition to Defendant's Motion in Limine (Middle District of Pennsylvania, 2017), 11.

40 U.S. prosecutors charged Brown with providing material support to terrorism in March 2014 after he attempted to board a flight in North Carolina bound for Turkey. See Office of Public Affairs, "Raleigh Man Pleads Guilty to Conspiring to Provide Material Support for Terrorism," U.S. Department of Justice, October 16, 2014, www.justice. gov/opa/pr/raleigh-man-pleads-guilty-conspiring-provide-material-support-terrorism.

41 Office of Public Affairs, "Illinois Man Pleads Guilty to Attempting to Provide Material Support to ISIL," U.S. Department of Justice, October 29, 2015, www.justice.gov/opa/pr/illinois-man-pleads-guilty-attempting-providematerial-support-isil.

42 U.S.A. v. Mohammed Hamzah Khan, Plea Agreement (Northern District of Illinois, 2015), 3-4.

43 Ibid.

44 Ibid.

45 Little is known about al-Sudani, who was better known online as Abu Isa al-Amriki, although he has been connected to a number of failed attacks and, under the name "HoneyNTea," used Telegram to run an Islamic State terrorist cell in India. See Callimachi, "Not 'Lone Wolves' After All."

46 Department of Defense, "Press Briefing by Pentagon Press Secretary Peter Cook," U.S. Department of Defense, December 19, 2016, www.defense.gov/Newsroom/Transcripts/Transcript/Article/1033978/ department-of-defense-press-briefing-by-pentagon-press-secretary-peter-cook-in/.

47 U.S.A. v. Mohamed Bailor Jalloh, Sentencing Memorandum (Eastern District of Virginia, 2016), 3.

48 Ibid., 4.

49 U.S.A. v. Mohamed Bailor Jalloh, Affidavit in Support of a Criminal Complaint (Eastern District of Virginia, 2016), 7.

50 Office of Public Affairs, "Former Army National Guardsman Sentenced to 11 Years for Attempting to Provide Material Support to ISIL," U.S. Department of Justice, February 10, 2017, www.justice.gov/opa/pr/ former-army-national-guardsman-sentenced-11-years-attempting-provide-material-support-isil.

51 Office of Public Affairs, "Ohio Man Arrested for Attempting to Provide Material Support to ISIL," U.S. Department of Justice, November 7, 2016, www.justice.gov/opa/pr/ohio-man-arrested-attempting-provide-material-support-isil.

52 U.S.A. v. Aaron Daniels, Criminal Complaint and Arrest Warrant (Southern District of Ohio, 2016), 7.

53 Ibid., 5.

54 Ibid., 6.

55 Ibid.

56 Ibid., 6-7. 


\section{Meleagrou-Hitchens and Hughes}

57 Ibid.

58 U.S.A. v. Emanuel L. Lutchman, Plea Agreement (Western District of New York, 2016), 4.

59 Ibid., 5.

60 Ibid., 6.

61 Ibid., 9.

62 Office of Public Affairs, "New York Man Sentenced to 20 Years for Conspiring to Provide Material Support to ISIL in Connection With Planned New Year's Eve Attack," U.S. Department of Justice, January 26, 2017, www.justice. gov/opa/pr/new-york-man-sentenced-20-years-conspiring-provide-material-support-isil-connection-planned.

63 Jennifer Rizzo, “ISIS Fighter, Wife, Killed in Airstrike, U.S. Says,” CNN, May 5, 2016, www.cnn.com/2016/05/05/ middleeast/isis-fighter-wife-killed/index.html.

64 Elton Simpson's online discussions with Hussain were presented as evidence for the prosecution in U.S.A. v. Abdul Malik Abdul Kareem (District of Arizona, 2016).

65 Rukmini Callimachi, "Clues on Twitter Show Ties Between Texas Gunman and ISIS Network," New York Times, May 11, 2015, www.nytimes.com/2015/05/12/us/twitter-clues-show-ties-between-isis-and-garland-texas-gun man.html.

66 Ibid.

67 Holly Yan, "ISIS Claims Responsibility for Garland, Texas, Shooting," CNN, May 5, 2015, www.cnn. com/2015/05/05/us/garland-texas-prophet-mohammed-contest-shooting/index.html.

68 U.S.A. v. Munir Abdulkader, Sentencing Minutes, 70.

69 James Eng, "FBI Director: Encrypted Messages Stymied Probe of Garland Shooting," NBC News, December 9, 2015, www.nbcnews.com/tech/security/fbi-director-encrypted-messages-stymied-probe-garland-shooting-n 477111.

70 Scott Shane and Fernanda Santos, "Elton Simpson Eluded U.S. Inquiry Before Texas Shootout," New York Times, May 6, 2015, www.nytimes.com/2015/05/07/us/elton-simpson-eluded-us-inquiry-before-texas-shootout. html.

71 Libor Jany, "Former Twin Cities Man and ISIL Recruiter Linked to Thwarted Terrorist Plots in U.S.," Star Tribune, July 3, 2015, www.startribune.com/former-twin-cities-man-and-isil-recruiter-linked-to-thwarted-terrorist-plotsin-u-s/311530601/.

72 Jim Sciutto et al., “Texas Attacker Tweeted with Overseas Terrorists," CNN, May 5, 2015 , www.cnn. com/2015/05/05/politics/texas-attack-terror-tweets/index.html.

73 For a comprehensive analysis of the Islamic State's plans to survive online, see Charlie Winter, Media Jihad: The Islamic State's Doctrine for Information Warfare (London: International Centre for the Study of Radicalisation and Political Violence, 2017).

74 “An Update on Our Efforts to Combat Violent Extremism," Twitter, August 18, 2016, https://blog.twitter.com/ en_us/a/2016/an-update-on-our-efforts-to-combat-violent-extremism.html.

75 The announcement was made on Twitter on November 18, 2015. Soon after, a user asked, "Oh, so do you intercept conversations?" to which the official Telegram twitter account responded, "No. Channels are public and available to everyone by default."

76 Paul Cruickshank, "A View From the CT Foxhole: Peter Edge, ICE Acting Deputy Director, and Wil van Gemert, Europol Deputy Director,” CTC Sentinel 10, no. 1 (2017): 11-16.

77 Cecelia Kang and Matt Apuzzo, "U.S. Asks Tech and Entertainment Industries Help in Fighting Terrorism," New York Times, February 24, 2016, www.nytimes.com/2016/02/25/technology/tech-and-media-firms-called-towhite-house-for-terrorism-meeting.html.

78 Kevin Breuninger et al., "Trump Is Trying to Link Stimulus Checks, Defense Spending to a Contentious Tech Protection," CNBC, December 29, 2020, www.cnbc.com/2020/12/29/why-trump-is-tying-section-230-to-stim ulus-checks-defense-bill.html. 